\title{
Jakobus Marthinus Vorster's ecclesio-political philosophy: A critical interpretation
}

\author{
Author: \\ Williams O. Mbamalu ${ }^{1}$ \\ Affiliation: \\ ${ }^{1}$ Unit for Reformed Theology \\ and the Development of \\ the South African society, \\ Potchefstroom Campus, \\ North-West University, \\ South Africa \\ Correspondence to: \\ Williams Mbamalu \\ Email: \\ mbamalu_christethics@ \\ hotmail.com \\ Postal Address: \\ P.O. Box 20679, Noordbrug \\ 2522, South Africa \\ Dates: \\ Received: 13 Feb. 2011 \\ Accepted: 14 June 2011 \\ Published: 24 Oct. 2012 \\ How to cite this article: \\ Mbamalu, W.O., 2012, \\ 'Jakobus Marthinus Vorster's \\ ecclesio-political philosophy: \\ A critical interpretation', \\ In die Skriflig/In Luci Verbi \\ 46(1), Art. \#42, 13 pages. \\ http://dx.doi.org/10.4102/ \\ ids.v46i1.42
}

C 2012. The Authors. Licensee: AOSIS OpenJournals. This work is licensed under the Creative Commons Attribution License.
This article is a critical interpretation and commendation of Jakobus M. Vorster's scholarly contribution to the field of ecclesiastical sciences, ethics and political philosophy. It shows that the imago Dei is a human creation of the image of God, a unifying concept in Vorster's scholarly writing. What was implied is that Vorster's ethico-biblical anthropology is the controlling thought in interpreting his ecclesio-political philosophy in this article. This is a proposed limitation of the essay rather than a limitation of Vorster as a person or his scholarly works in general.

Jakobus Marthinus Vorster se ecclesio-politiese filosofie: 'n Kritiese interpretasie. Hierdie artikel is ' $n$ kritiese interpretasie en huldiging van Jakobus M. Vorster se navorsingsbydrae tot die geestelike wetenskappe, etiek en politieke filosofie. Dit openbaar die eenvormige konsep in Vorster se navorsing, naamlik dat die imago Dei ‘n menslike skepping van God se beeld is. Die implikasie van hierdie artikel is dat Vorster se eties-bybelse antropologie die hoofoorweging is in die interpretasie van sy geestelik-politiese filosofie. Hierdie artikel is slegs 'n beperkte aanbieding wat nie ' $n$ beperking op Vorster as persoon of sy navorsing impliseer nie.

\section{Introduction}

The specific choice of this topic stems from the realisation that personal reflections are not out of place in academic scholarship. Many a time, philosophy is a matter of standing back a little from ephemeral urgencies to take an aphoristic overview that embraces both the value commitments and beliefs of a scholar.

Most philosophers, instead of starting from the accumulated authority of the medieval tradition, began with their own experience and philosophised from there. Jakobus M. Vorster is guided by the canons of rationality as his philosophy seeks inquiry into many subjects of socio-political and economic concerns.

The methodology employed in this article is two-pronged: firstly, the article is expository in nature and secondly it is a critical exercise. The rationale for this approach is that a critique is best done when it follows a thorough and robust analysis and exposition of a system of thought. The intention here is to map out some of Vorster's basic ideas and concepts and bring them into dialogue with the ideas of some philosopher-theologians who Vorster admired or identified with. A greater portion of the sources and citations for this article are derived from Vorster's published books and articles, so that the man, as much as possible, is allowed to speak for himself on the issues at hand. In general, reference could be made to the writings and scholarly works of other academics.

The work is divided into six main parts: the first part, which is architectonic, captures the background of the article from 1946 to 1966 and covers the biographical exploration of Vorster's life, and some historical developments during that period and concludes with Vorster's scholarship and research interests. The second part engages Vorster's ethico-philosophical anthropology, which serves as the hub of Vorster's ecclesio-political and theological thought about humankind. The third part engages the ethico-political issues in which Vorster deals with nation-building, land restitution, homosexuality and a host of other social, political and ethical issues. The fourth part focuses on racism, xenophobia and human rights, whilst part five is a critical evaluation that drives the article towards a conclusion in part six.

\section{The background to Vorster's thought (1946-1966)}

Jakobus M. Vorster was raised and educated entirely amongst reformed Christians and has embedded within his manifold written works, an ecclesio-political philosophy, which compares favourably with any other scholarly work in the world and particularly in South Africa. 
Vorster's life and scholarship merits consideration, study and knowledge. The usage of the term philosophy is justified in this article because any response to the question, 'What is philosophy?' must point towards the bookshelves of Vorster: philosophy is what all the books on his shelves are about. Jakobus Marthinus Vorster was born on 12 December 1946 in Johannesburg. The year of Vorster's birth coincides with important major world and local events, such as the meeting of the first general Assembly of the United Nations, in London England in 1946. In South Africa, 1946 was the year in which a number of critical events occurred that shaped the life of Nelson Rolihlahla Mandela. It was the year in which 70000 African miners on the Reef went on strike (Mandela 1994:117). It was a strike that brought South Africa's core industry - mining - to a halt. As Mandela recounts, circumstances in 1946 forced him to recast his whole approach to political work. It was in 1946 that the Smuts government promulgated what was called the Asiatic Land Tenure Act, which curtailed the free movement of Indians. This Law - known as the Ghetto Act - led to a concerted two-year campaign of passive resistance by the Indian community in South Africa. The campaign, Mandela recounts, became a model for the type of protest that the African National Congress (ANC) Youth League were calling for (Mandela 1994:119).

From 1953 to 1964, Vorster completed his primary education in Johannesburg and Roodepoort. During those impressionable childhood years at primary school, Vorster was beginning to perceive the importance of human rights. Two laws passed in 1950, when Vorster was four years old, formed the cornerstones of apartheid: the Population Registration Act that authorised the government officially to classify all South Africans according to race. Vorster (2004:139) would grow to write against racism, xenophobia and human rights issues in South Africa, his land of birth. It was known as the Group Areas Act, which initiated the era of forced removals of peoples from their communities and relocated them far away from White landowners (Mandela 1994:140). The formative years of Vorster's life as a young boy in primary and secondary schools from 1953-1964, under the shadows of an apartheid government, no doubt ignited in him the sociopolitical and ecclesial thoughts that directed his life-chosen career as clergy, educator and ethicist. As a young student, Vorster was already idealistic and had taken cognisance of the social injustice, the fagging and unequal treatment of people under the apartheid government in South Africa. Vorster would recall that 'the South African system in the period of 1948-1994 was a good example of a one-dimensional state. All spheres of life, even morality, sexuality and marital life were controlled by the state' (Vorster 2004:143). Given these sociopolitical conditions at that time, the urge soon developed in Vorster to embark on studies that would launch him as a teacher of righteousness and justice. From 1968 to 1984 Vorster achieved the following degrees: BA (1968); BA Hons (1968); MA (1971); ThB (1974); DPhil (1978); and ThD (1984), all from Potchefstroom University for Christian Higher Education. ${ }^{1}$ It was at this Christian university that Vorster's

1.The Potchefstroom University for Christian Higher Education, now the North West University, was founded as a Christian university by the Dutch Reformed Church (DRC) to offer Christian education to scholars of different professions within the university. ecclesio-political philosophy was well and truly laid. The members of this Christian university constituted most of the strongest critics of the apartheid regime. The Institute for Reformational Studies (IRS) of the Potchefstroom University for Christian Higher Education at that time, was the platform for most of these scholars to write and teach courses that affirmed the doctrines of Christian biblical principles in a world God so loved and died for. ${ }^{2}$

The first 20 years of Vorster's life, from 1946-1966, would be seen as foundational for the formation of his ecclesiopolitical thought. Later, he would embark on two doctoral dissertations in which he engaged in his DPhil "The Church and the question of Colour' and for his ThD 'The Neo-Marxist Political Theology in South Africa'. ${ }^{3}$ Further researches were to follow in Berlin, New York, Bonn, Canberra and Geneva, on political ethics and the influence of Neo-Marxism on the World Council of Churches and the Reformed Churches in the Netherlands. What began to take shape in Vorster's impressionable mind from his exposure to the political realities of apartheid South Africa as a young schoolboy, would be passionately confronted in research and writings in the next 43 years 1967-2010. In these years of intense research and teaching, Vorster's ecclesiopolitical philosophy must have come from at least two predominant sources: firstly, it must have come from himself as a scholar who embodied the apartheid experience. And secondly, his scholarship was influenced by philosophertheologians such as Martin Luther (1483-1546); John Calvin (1509-1564); Abraham Kuyper (1837-1920); Karl Barth (1886-1968); Thomas Kuhn (1922-1996); Moltmann (b. 1926) and numerous other political thinkers. Due to the limitation of space, two influential theologians are examined: Calvin and Kuyper.

\section{Influences Calvin and Kuyper}

It would be fair to admit that Reformed churches in South Africa have their roots not only in the Calvinistic Reformation of the 16th century, but also in the renewal and resurgence of Calvinism that took place under the very different circumstances in the Netherlands of the 19th century. Analysis of the development of Vorster's thought would not be complete and profound without reading through his works to ascertain the philosophers, theologians and events that provided the sources for his ecclesio-political philosophy.

\section{John Calvin (1509-1564)}

Like Luther, Bucer, Zwingli, John Knox and others, Calvin believed that Christians should go into the world to act as the leaven which influences and changes the character and

\footnotetext{
2.The IRS of PU for CHE had at that time philosopher theologians such as B.J. van der Walt; J.D. van der Vyver, P.J.J.S. Potgieter; Piet J. du Toit; S.F. Coetzee, Johan van Vyver, Tjaart van der Walt, Elaine Botha, Theuns Eloff, Amie van Wyk, and J.M. van Vyver, Tjaart van der Walt, Elaine Botha, Theuns Eloff, Amie van Wyk, and J.M.
Vorster amongst others. One must not quickly forget people like H.G. Stoker who Vorster amongst others. One must not quickly forget peopilosophical-ideological grounding for apartheid.
gave a phid

3.These dissertations are all written in Afrikaans, but Vorster has reflected the contents of these works in most of his published books and journal articles.
} 
tendencies of the earthly kingdom. For Calvin, Christians should seek to restrain the earthly kingdom's desire to declare its independence from God, an independence, that can only bring about its own destruction in judgement. The Kingdom of God should, by the activities of Christians, exercise an effective and beneficial influence on history, bringing humankind into its citizenship and restraining the sinfulness of those who choose to remain outside (Eph 2:11ff.; see also Reid 1957:44). It is from Calvin's theology that Vorster derives his ethical vision of society, church and the state. In this way, Vorster's ecclesio-political philosophy is informed and firmly rooted in reformed theologies. 'Reformed' means rejecting the idea that tradition can provide a sufficient form for matters of belief. For Vorster, the Word of God was the only ultimate source of appeal in matters of faith, ecclesiology, philosophy and all other sources of knowledge, including a church's tradition. As a matter of fact, reformed theologies are primarily centred on God, based on God's Word alone, committed to faith alone, devoted to Jesus Christ and structured by three covenants of redemption, works and grace. A keen reader and observer would discover that Vorster's ecclesio-political philosophies exhibit the veins of these major reformed tenets of faith.

'Calvin's theology' says Partee (1995:209) 'is a permanent resource for Christian reflection. Its pastoral context is Geneva, where Calvin labored from 1536 to 1564 as pastor, preacher, teacher and writer.' A closer scrutiny of Vorster's ecclesio-political philosophy reveals the influence of Calvinist political theory often acknowledged as the fountain of much of modern political thought. Vorster (2004) would argue that:

Calvin ... was first and foremost a theologian who intended to reform the theology and church of his time. Therefore, his point of departure was founded in theological presuppositions. In the course of his theological development and a result of the pressures of his socio-political context, he applied his theology to the political order of his day. In this process he provided an ethical base for the development of Reformed political thinking. (p. 28)

Basically Calvinist political theory is a kind of theory of government, which takes 'an essential character from Calvinist theology and cosmology' (Marshall 1991b:2). In fact, reformed ethics continues to find its source and standard in the work of Calvin. Vorster would use most of Calvin's thesis to propound that love, a reformatory, peaceful and non-violent means as the best option when dealing with the socio-political problems of post-apartheid South Africa. Vorster (1999) acknowledges Calvin's influence when he writes:

Calvin has influenced to a large extent the development of Reformed Church Polity in France ... and later in South Africa. Calvin's ideas have also influenced ecclesiastical resolutions about Church Order by the early Reformed synods ... (p. 4)

When writing on Reformed Church Polity, Vorster (1999) does not cling to Calvinism in a lifeless rigid fashion. He would rather advise that in the administration of Reformed Church Polity the following hermeneutical principles become important:
- A clear definition of the paradigm that is used, is necessary. The frame of reference should be defined with acceptance of the possibility of a shift in paradigm and the biblical limitations of such a shift.

- The historical context and development of the Church Order should be kept in mind. The initial intention of the Church Order must be defined. (p. 10)

From this vantage point, Vorster displays a liberal perspective and respect for the Southern African contexts. Thus, his book An Introduction to Reformed Church Polity (Vorster 1999) remains indisputably a working tool for the different groups in the Dutch Reformed Churches in South Africa, that agree to be guided by such document so that meetings would be conducted orderly. Also, Vorster's ecclesio-political philosophy takes its source from Abraham Kuyper (1837-1920), a brilliant and productive Christian leader, who founded the Free University of Amsterdam.

\section{Abraham Kuyper (1837-1920)}

Like Kuyper, Vorster's concept of church polity as a science with a character of its own, finds its root in the postulation that the 'distinctiveness of the Church Polity is based on the fact that the Bible and the confessions are its main source' (Vorster 1999:1). Kuyper was a prominent leader of the influential Dutch neo-Calvinist movement who provided a highly original and forceful presentation of the Calvinist 'world-view,' at the base of which was a confession of the universal sovereignty of God over all aspects of creation (Chaplin 1995:533). Much of Calvin's socio-ethical philosophy was not attended to because firstly, the churches in Europe were more concerned with the restoration of the church itself. 'Reformed Christianity was embroiled in a fierce struggle against the secularism of the Enlightenment and was suspicious of the ideas of the French Revolution, including human rights' (Vorster 2004:51). Secondly, the influence of the Dutch jurist Groen van Prinsterer (1806-1876), who argued in favour of the freedom of the Dutch nation over and against the major European powers of his day, must not be overemphasised when dealing with the emergence of Kuyper. According to Vorster, Prinsterer reinterpreted Calvin's theocracy and charged that the practical implementation of the idea of theocracy was Calvin's weak point in his otherwise sound explication of the calling and responsibility of civil authority (ibid.). 'Van Prinsterer's influence contributed to the indifference of the Reformed tradition in Netherlands regarding human rights' (ibid.).

This indifference had to change and Calvin's social ethics had to be reinstated. The man who would later influence the socio-political thought of many scholars, political and church leaders was the Dutch theologian and politician Abraham Kuyper (1837-1920). Even though there are various theories concerning the beginnings of the nation-state: the social contract theory, the divine right theory, the force theory, the patriarchal theory, the matriarchal theory and the evolutionary theory (Appadorai 1961:19ff.), Kuyper did not 
accept or approve the concept of the state as a social contract. The social contract firstly finds expression in Hooker's The Laws of Ecclesiastical Polity (1594-1597), where he postulates an original state of nature in which humankind is subject only to the law of nature (Vorster 2004:51). Kuyper rather defined his political thinking as anti-revolutionary:

[E]mphasising that the responsibility of Christians must be to actively involve in the socio-political sphere and vehemently reject any notion of a pietistic distance between the Christian religion and social life. (Vorster 2004:52)

Vorster as an intrepid witness of apartheid would imbibe Kuyper's philosophy when dealing with pressing human rights issues in South Africa. Kuyper places the concept of human rights within the sphere of the civil authority and social ethics thereby reviving the ideas of Calvin (Vorster 2004:52). Vorster will amplify these ideas when he deals with volatile socio-ethical issues in post-apartheid South Africa liberal democracy. Though, not in a wholesale fashion, both Kuyper's and Calvinist's orthodoxy form the bedrock of Vorster's engagement with local and international volatile ethico-political issues. However, in the main, Vorster's ecclesio-political philosophy revolves round his perception of humans, that is his anthropology and to which we must now turn.

\section{Vorster's ethico-philosophical anthropology}

The general issues discussed above have proved to be a leverage background, and we can now proceed to examine the essence of Vorster's ecclesio-political philosophy, which revolves round his anthropological philosophy. What is Vorster's anthropology and how does he view humans? Is man or woman the central theme of Vorster's ecclesiopolitical philosophy? Much of Vorster's work defines the human being from the perspective of Christian ontology. In all his works, he displays vividly his rejection of a mechanistic view of human beings as Descartes and Kant did. When humans are being mechanistic, they are seen as lacking a free will, hence as lacking responsibility and intrinsic value altogether. An outstanding credit to Vorster's scholarship is his adoption of a phenomenological methodology that shows that his knowledge of humankind is not based directly on clinical or laboratorial tests and verifications, but mainly on his close observation and personal experience of human nature as described in the Bible. ${ }^{4}$ Further, what is the composition of human personality? Is there something special about humans, a soul or mind that persists through change and survives death? Is there something that constitutes the human being's true identity and is the locus of eternal value? Does Vorster hold a dualistic or materialistic theory of the human? Vorster did not make the philosophical discussion of human physiology, faculties, instincts, genes and environment his preoccupation. Even when he wrote the book Christian Attitude in the South African Liberal Democracy (Vorster 2007), he adopted a Christological prescriptive approach in which he charged humans to imitate Christ. The

4.Three parts of Scripture (Gn 9:6; Ja $3: 9$ and Ps 8:6) are of special importance to Vorster for the comprehension of imago Dei. mind-body relationship, which for ages has been the subject of philosophical reflection, was not integrated in Vorster's treatment of the Christian attitude and the concept of life as an ethical principle for the human rights debate. This in a way raises the curiosity to situate the concept of the human nature in the ethical discourse of Vorster. Even though the concept of imago Dei, which Vorster accepts, is taken for granted, it is crucial to explore some of the qualities that make humans different, unique or behave the way they do. This aspect is very crucial in South Africa's multi-racial society, where equality is preached with less regard to the fact that nature disburses and distributes its talents and resources freely, but unequally. The political implications of nature or nurture are very controversial, especially when one thinks of Hitler's myth of the Aryan race, and the superiority complex of the White persons who formed the base of engineered apartheid in South Africa. Vorster is aware of this, but does not entertain this issue strictly speaking. Further, he is aware that 'the superiority of some groups and inferiority of others are subsequently used to legitimate the unequal distribution of the society's resources, specially, various forms of wealth, prestige and power' (Vorster 2004:141). In order to understand the ethical and socio-political behaviour of people in post-apartheid South Africa, the soul and/or mind-body relationship can necessarily be nuanced in Vorster's anthropology.

\section{Soul-body relationship}

It is important to briefly discuss the philosophical doctrine of the soul-body problem and offer reasons why Vorster would not bother to integrate this important subject in his treaties. It was Plato who proposed a doctrine of an immaterial, immortal and pre-existing soul that is imprisoned in a body (Plato 1928a:120ff.). A synthetical attempt at reconciling this view was made by Aristotle and Thomas Aquinas. In the 17th century, René Descartes who was the first to develop a systematic theory of the soul and the relationship between mind and body, challenged the position of Aristotle and Aquinas. For Descartes, both mind and body are distinct substances: the soul is thinking and extended, whilst the body is unthinking and extended in space and time. What this means in effect is that, the body in spite of its cosmic extension, does not affect or influence the soul with its activities. It is an autonomy that does not engage in any mental activity. In short, the mind being withdrawn does not influence the body - each entity is on its own. The human being is indeed caught up in the web of struggles for control between soul and body and easily goaded by the dilemma of following the flesh or submitting to the dominion of the spirit. Socrates would say:

For the body is a source of endless trouble to us by reason of the mere requirement of food; and is liable also to diseases which overtake and impede us in the search after true being; it fills us full of loves, and lusts, and fears, and fancies of all kinds, and endless foolery, and, in fact, as men say, takes away from us the power of thinking at all. (Plato 1928a:120)

How does Vorster handle this problem when dealing with ethical perspectives on human rights, freedom of belief, 
women and children? The creation motif in which God made human beings in his own image and likeness is the ground of Vorster's anthropology. The imago Dei remains very prominent in Vorster's theology, but he did not have the space or time to pursue in detail the views of Stoics, Aristotle, Augustine, Ramsey, Descartes, Locke or Hume. Vorster sees humankind as completely unique and different from animals because a human being is Homo dinamicus, which is to say that humankind is the only principle as well as the goal and end of all activities in the cosmos. He would maintain that 'man's [sic] imaging of God and the cultural mandate has direct ethical implications; it is man's [sic] task to nurture and conserve the life that God has created' (Vorster 2004:81). In essence, without human beings, nature remains passive and in a state of inertia; there would be no change, progress, development, culture and civilisation. For Vorster the concept of life with its preservation is a great ethical issue. He completely forbids the decimation of human life and states that 'Life as God's creation must indeed be protected and unfurled.' (Vorster 2004:81).

Vorster (2004:92) does not have much trust or faith in human beings, because for him human beings are fickle and depraved, 'the fall of man and its consequences forms an essential element of the Christian anthropology'. Furthermore, for Vorster (2004):

$[T]$ he fall of man means that man is totally depraved ( $\mathrm{Rm} \mathrm{3:10).}$ This depravity runs along the entire human race along the line of the original sin (Ps 51:7; 1 Cor 15:22). The fall of man estranged man from God. (p. 93)

Ethically, 'total depravity does not mean that man must see his fellow men as damnable and should treat them as such. There are no grounds in Scripture for such anthropology' (Vorster 2004:93). In other words, what Vorster infers is that the fall of humankind does not affect the dynamism of humans. The indestructibility of the imago Dei in the human being guarantees to man the ability to create structures that are political, religious, social and economic in nature. In Calvinist theology, 'the likeness was tarnished, but not destroyed' (ibid.). The indestructibility of the imago Dei also means that humankind has concrete freedom to exercise his power over nature. Human freedom entails the following principals, namely physical freedom, intellectual freedom, moral freedom, psychological freedom, social freedom, political freedom and religious freedom. ${ }^{5}$ But does human freedom operate under the principle of determinism? Or does it operate under natural law, Divine law (the Ten Commandments), or civil law? Vorster's philosophical anthropology adheres to the Calvinistic natural law tradition for the enjoyment of political stability.

\section{Natural law or universal moral law}

There is no gainsaying about the phenomenon and reality of law for Vorster, because the cosmos is governed by

5.In physical freedom, no human should be constricted with regard to the process of the law; social freedom is such that every human being is not negatively of the law, social freedom is such that every human being is not negatively programmed by birth, status and class from attaining set goals or the realisation of one's potentials and talents in the society; political freedom accords selfdetermination on persons without the imposition of political rule on any group of people by another. The apartheid government tended towards imposing its politica rule on groups in South Africa. No majority group in post-apartheid South Africa must directly or by proxy adopt a hard-line method in dealing with other groups in the country.
Law. Vorster summaries the definition of natural law from Spykman's and Calvin's writings and submits that 'natural law means that all people, believer or non-believer, has moral conscience; in spite of sin man can make moral choices' (Vorster 2004:96). From the foregoing, it appears Vorster believes that human beings are not determined extrinsically. Extrinsic determinism is a theory that is expressed in two forms: mythological ${ }^{6}$ and theological. Theological determinism states that humans are not free and responsible for their actions because the omnipotence of God prevents them from doing so. It is the intrinsic determinism, which Vorster embraces much more than the extrinsic determinism. He sees this intrinsic determinism as that innate sense of righteousness, which König brings under the old reformed concept of 'common grace'; God's common grace guarantees that society does not totally degenerate (ibid.). ${ }^{7}$ Thus Vorster's ethico-political philosophy and anthropology are grounded on God's Divine purpose, which from the foundation of the world was to recreate a new humanity in Christ. Vorster's reason is to subject all things to the Word of God and the supremacy of Jesus Christ. Thus, Vorster denounces the political doctrine of Jean Paul Sartre who believes in freedom, but equates and substitutes it with the essence of the human being itself. Human freedom must be expressed and protected by the government, but under what type of government must this happen? Vorster admits that theocratic government operated in the Old Testament, but the New Testament dispensation does not prescribe or provide 'any blueprint for a political policy' (2004:98-99), and that any meaningful form of government, could function on 'the grounds of the ethical focus of Scripture' and 'must be determined anew in every new situation' (Vorster 2004:99). The dream is to have a state where religious freedom becomes a condition for the existence of society and social life. The kind of state open to Vorster to launch his socio-political pad is a government of a common religion state, a common language state or a nation-state, where one dominant ethnic group comprises the citizenry and rules the country. But how does this agree with the views of Van der Walt and Naudè who theorise that 'A nation-state will not be possible in South Africa; neither a common language nor a single religion-state' would be suitable for South Africa (Van der Walt \& Naudè 1996:8). Vorster is aware of this and would invoke Locke's view of state in which the state rests upon a social agreement between individuals (Vorster 2004:99). In summary, Vorster proposes that constitutional democracy gives the best expression to Christian-ethical principles, because after the Second World War, it bore the fruits of peace, justice, prosperity and selfdetermination (Vorster 2004:99-100).

On this perspective, Vorster (2004) demonstrates implicit optimism in the society and/or citizens as the right group with:

[T] he powers to constitute the government for the sake of the orderly unfurling of life; A government that cannot be dismissed

6.The mythological theory basically states that a human being is not the master of his or her acts but influenced and controlled by the stars, ancestors, the gods and demonic forces. The medieval Greco-Romans had this theory spread amongst their people, as well as present-day Asians and Africans.

7.Vorster would identify with Calvin who understands that the law engraved in the human heart as wider than the Ten Commandments. This is the natural law that human heart as wider than the Ten Commandments. This is the natural law that
endows all human beings with a moral conscience to make moral choices and exercise a sense of righteousness. 
by citizens in an orderly fashion does not measure up to the right to exercise authority. (p. 99)

However, Vorster is aware that the Lockean society was the matrix of hardcore or classical capitalism of the 17th and 18th centuries that remotely feathered colonialism in the 19th century Africa, Vorster's home continent. Vorster cannot be subjected to the assizes on the basis of his ambient admiration for a Lockean society because his view of society is not that of a critic and idealist, but of a theologian and a Christian ethicist. Furthermore, Vorster's approach to the definition of the nature of the society is ontological and economic; it is intrinsic and extrinsic. By pairing the ontological and the intrinsic, Vorster maintains his theological position that God created humankind in his own image, the imago Dei. By pairing the economic and the extrinsic nature of the society, Vorster establishes his vision of a society where 'salvation in Christ and regeneration by the Holy Spirit turns the attitude away from selfish desires to the interest of others' - a major theme in Christian anthropology (Vorster 2004:111). In fact Vorster endorses the classical view of society based on ontological reasoning because for him, socialisation is the continuation of creation, for 'God created everything good' (Vorster 2004:91). Most assuredly, Vorster possesses an integrated view of the human. For him, a human being is a person made in the image of God, made of body, mind and soul, elements that are intrinsically and mutually interrelated. For this reason, humans need to have a society in order to enjoy freedom that is expressed, in the case of South Africa, in nation-building, in land restitution, in the protection of children, homosexuality, and the role of the churches, human rights and moral conflicts, the right to life, the rights of minorities, and many others all of which, directly or indirectly impact on Vorster's anthropology. In short, the human being is the basis and foundation of Vorster's ecclesio-political philosophy ${ }^{8}$ and the family is an unviable social entity that cannot produce everything it needs. In most cases, large families may combine to constitute a minority in a society. When it, therefore, teams up with others in nation-building, its political, cultural, educational, linguistic and religious interests must be protected intact (Vorster 2004:170). The union or aggregation of families, not the individual, ${ }^{9}$ becomes the focus of Vorster's theo-social philosophy for nation-building.

\section{Nation-building and land restitution}

Vorster is consistent in his description of the fallen human nature as it affects nation-building, human rights and moral conflicts. He creatively relates nation-building as a collective moral responsibility devoid of race and geography, to Christology. For Vorster, there is no clear distinction between Old Testament and New Testament ethics, this is

8.It would be in order to speak of Vorster's socio-political philosophy instead of his ecclesio-political philosophy. What is significant about the contribution of Vorster to social philosophy is the emphasis on the maintenance of the human family and in the society (refer to Vorster's Christian attitude in the South African Liberal Democracy 2007).

9.Vorster is not in the class of philosophers who make it their task to idealise and idolise the individual to the detriment of the whole society. In the societies of Locke and Rousseau individual members guarded their freedom too jealously and violently. because the Scripture (Sola Scriptura) in one voice speaks to all human conduct. Most proponents of Christian ethics have freely employed Greek philosophical ethical principles in dealing with contemporary moral issues. Vorster will rather universalise Christian values by translating them into human rights language when he discusses deontological and consequential ethics (Vorster 2007:11). He will, however, firmly maintain that:

Christian ethics flows from the revelation of God. In his acts in nature and history, and especially in his self-revelation in His Word, God laid down the deepest principles for moral conduct. From these principles norms can be derived for human lifestyle. God created the sense of morality in every person and enriched this gift with the moral teachings of Scripture. (Vorster 2007:3-4)

One of the key issues in Vorster's political-anthropology is how to bring about a stable and sustainable transition to plural democracy, reconstruction and development in postapartheid South Africa. In this regard, his philosophy is rooted in three motifs of Calvin's cosmology. ${ }^{10}$ Firstly, that the whole of creation is equally under God's sovereign will; secondly, that the institutions of society are not arranged hierarchically, but are differentiated according to vocation and are arranged side by side in mutual support of one another; and thirdly, that God's work is carried out by the free, voluntary obedience by God's people (Marshall 1991b:17). In this regard, Vorster (2007) defines nation-building:

$[A] \mathrm{s}$ the social process of transforming an underdeveloped, poor and divided society into a community with peace, equal opportunities and economic viability. In such a community individuals should enjoy dignity, basic human rights and the prospect to observe their own religion, tradition, culture and language in harmony with other people who may function within other traditions. (p. 22)

Even though Vorster's principle of nation-building aims at the happiness of each and every citizen, the state he contemplates, which has the competence and power to make laws and constitution, must be based on the principles deduced from the natural law (Vorster 2004:96). ${ }^{11}$ Vorster's view of society resembles that of Appadorai (1961) who says:

[S]ociety is an association of human beings and suggests the whole complex of the relations of man to his fellows. It consists of the complicated network of groups and institutions expressing human association. (p. 13)

However, human society must have human nature itself as the intrinsic divine principle, if it is to conform with the spirit of the Ten Commandments in which 'God demands righteousness from deprived [sic] man'. ${ }^{12}$ Reading through the works of Vorster, however, one finds that he propounds a theology of society from a holistic Christian ethical perspective with less regard to those who naturally would not come under the Ten Commandments. One must not forget that from the 10.On this see Calvin's 'Argument' of Commentary on Genesis, volume 1 (1948:57)

11.Says Vorster in Ethical Perspectives on Human Rights, 2004 'Man's likeness to God and natural law as the realization of norms by man, springing from the general goodness of God, therefore establishes human dignity, human duties and human goodness
rights.'

12.Vorster maintains that 'God gives the Ten Commandments to humanity ( $\mathrm{Rm} 2: 16)$. That which is right, must be established through the observance of the Ten Commandments' (2004:96). 
outset Vorster imbibes Thomas Aquinas ${ }^{\prime 13}$ moral theory that the natural law is founded on the basis of human nature itself so that the rule and measure of human acts is the reason, for it belongs to reason to direct human activity. It is from this vantage point that the ethical nature of politics strikes merit in Vorster's land restitution discourse.

\section{Land restitution}

No conflict or clash of ideals has played a more significant role in breaking down relations amongst various races in South Africa than the implementation by the National Party of its apartheid policies in the late 1940s and the early 1950s. ${ }^{14}$ It was during this period that the notorious Population Registration Act 30 of 1950, the Prohibition of Mixed Marriages Act 55 of 1949, and the Group Areas Acts 41 of 1950 were implemented. The Nationalist's stringent enforcement of this legislation overturned the lives of many Black South African people and negatively impacted on the property market. Following the Restitution of Land Rights Act 22 of 1994, a new dimension into the socio-ethical and political context of South Africa was introduced. In dealing with the restitution of Land Rights Act, how far, and no further could restitution go in South Africa? Could it well go far beyond the limits of compensation only for land rights lost, or could compensation also be paid for actual provable financial loss and the inconvenience and distress arising from the fact that people were forcefully removed from their land? Are the courts ready to respond to the questions regarding compensation for loss of work opportunities and residence rights? The Restitution of Land Rights Act 22 of 1994 makes provision for either possible restoration of land lost during the relocation of communities or monetary compensation if it can be proved that original compensation was not adequate. But how does the court or the Regional Land Claims Commission validate claims in cases where no formal records still exist? These questions though - not directly tossed at Vorster - are pertinent in furthering the land restitution discourse.

Vorster's approach to this sensitive and knotty political issue of land restitution is multifaceted. Firstly, he deals with the matter from the 'Christian ethical perspective of land ownership'; secondly he makes extensive allusion to the documents of the Universal Declaration of Human Rights; and lastly the post-colonial paradigm is creatively tailored into his argument. Article 17 of 1948 of the Universal Declaration of Human Rights says, 'Everyone has the right to own a property alone as well as in association with others.' Is the private ownership of land a fundamental human right? Vorster would argue that the right to land ownership is merely a moral ideal and cannot be seen as a fundamental right because it is not economically feasible. For Vorster, the right not to be arbitrarily dispossessed must be regarded as fundamental. How then would one underscore the actual aim and objective of the land clause in the Universal Declaration of Human Rights as the right of access for every member

13.See Frederick Copleston's profound treatment of St. Thomas Aquinas-IX: Mora Theory in his book, A history of philosophy: Medieval philosophy (1950:398-411).

14.The events of the 1940s and 1950s have been briefly discussed in the background to Vorster's thought. of a community? In other words, should the right to land ownership be enforced by a court of law in a constitutional democracy to compel a government to provide land to all its citizens? And how are historic imbalances to be rectified?

Vorster made extensive reference to the communist regimes, colonial times and the apartheid system in South Africa under which land and property were dispossessed and people lost their right to acquire land. Vorster's background story of land dispossession in South Africa recalls that 'European settlers in South Africa seized land and justified it with certain Christian convictions flowing mainly from a specific literalist interpretation of Old Testament ethics' (Vorster 2006:686). This literalist interpretation claimed that the indigenous tribes are pagan nations who must be disposed of their land to establish a Christian state:

The British colonial policy also implemented the missionary character of Christianity to justify colonisation. This idea entailed that colonisation is better for everyone because it would bring the 'light of Christianity' to a pagan country. (Vorster 2006:686)

The theological perspectives of some Christian scholars (see C.J.H Wright 1990:19) claim that the Old Testament principle of land acquisition and management has been fulfilled and surpassed with the coming of the Messiah ${ }^{15}$ therefore Christian ethics can develop norms for land estate management. These norms according to Vorster are:

- Tenure is permitted although it must be seen within the framework of divine principle in property management. This principle entails that stewardship becomes the main principle in property management ... The property owner, as steward, should manage his property in such a way that others may benefit from it and poverty can be kept in check.

- ... land ownership should not lead to monopolies of individuals or groups and should not be administered in such a way that some parts of the community are enriched and others are impoverished.

- Possession of land should be considered against the background of the calling to share and to live in the spirit of fellowship. Land ownership should serve the purpose of reconciling people and preventing social divisions.

- Land should be utilised in a responsible way for the social and economic well-being of the community.

Vorster (2006) sums up these norms by saying:

[T] hat possession of land with the 'holy motive' of developing a Christian state or to bring the 'light of civilisation' to indigenous peoples, as was the aim of the European settlers in inter alia Africa, violated these norms. (pp. 689-692)

The fact is that any programme of land restitution or equitable redress is necessary in order to create opportunities for all and to eradicate the imbalances of the past. Such embarked upon property redistribution must take cognisance of public interest of both the previously disadvantaged groups as

15.See Vorster (2006:689-692). This theology has consequences for present-day Israel in relation to the Middle East land conflict. It is possible to use this contentious theology to affirm that Jewish land as deeded to Abraham, Isaac and Jacob has been surpassed with the coming of the Messiah Jesus Christ, and therefore, present-day Israel does not exist or rather has been displaced by the Church 'the New Israel'. 
well as the landowners at the time of redistribution. In other words, expropriation to benefit some must not lead to the impoverishment of others. For this reason, Vorster (2006:700-702) sets clear ethical norms for land redistribution in a national context in this manner:

- In a divided community, the process of land redistribution should aim to redress the injustices of the past, but also to serve the process of reconciliation. Redress and reconciliation must be considered as the two pillars of a reform program. Land reform must not lead to further division and animosity in a community at large.

- ... a historical date, indicating the commencement of the era of dispossession and injustices must be agreed upon, as well as a sunset clause for claims. In South Africa, the Land Act 27 of $1913,{ }^{16}$ which led to the dispossession of Black people's land, was chosen as the date ushering in the period of legal claims.

- Restitution should start with state-owned property ... that was dispossessed due to the colonial doctrine. Restitution of such property demonstrates the collective responsibility of the previous advantaged community.

- The government of the day must pay fair compensation to the present owner and his employees. ... a present owner cannot be held responsible for the injustices of the past. Furthermore, fair compensation by the government is also a symbol of collective responsibility of a whole community in rectifying injustices of the past. People losing their means of survival when the land they live and work on is redistributed should also be compensated. Otherwise land redistribution will create poverty instead of development.

- New owners should be trained and educated to utilise land as responsible stewards. To repossess utilised land and to redistribute it in such a way that it is not utilised profitably endangers growth and development.

- Land redistribution itself may not always be possible, but redress can take other forms such as providing job opportunities, education, or housing. In other words, a disadvantaged person may perhaps not receive the land back he lost or other land, but he can be compensated through other means to rectify his material losses. ${ }^{17}$

The most critical contribution Vorster makes regarding these norms is to remind us that 'the ownership and the use of land are deeply related to humankind's calling to stewardship;' and that 'ownership and stewardship are two sides of the same coin' (Vorster 2007:60). Vorster's postulation brings us to Calvinist ethics that stressed useful work and calling in his commentary on the parable of the talents (Lk 19:1127). André Biéler (as quoted by Marshall 1991a), described Calvin's position in this manner:

Companionship is completed in work and in the interplay of economic exchanges. Human fellowship is realised in fellowships which flow from the division of labour wherein each person has been called of God to a particular and partial work which complements the work of others. The mutual exchange of goods

16.This act was repealed by section 1 of Act 108 of 1991 .

17.Vorster's conviction is that these Christian ethical norms well-satisfy the South African Constitution, Section $25(6-9)$ where the topic of land restitution is addressed. and services is the concrete sign of the profound solidarity which unites humanity. (p. 5) ${ }^{18}$

The point of departure here calls for a pertinent critical insight: the early European 'settlers' used religious and socio-political stories to define the people whose lands were seized or dispossessed. What story are the people using to define themselves in relation to the present-day Europeans in South Africa? In South Africa, the story of land is linked to the ancestors, how does the European fit into the equation of ancestral heritage in South Africa? From this perspective, any program of land restitution in South Africa must seek to remove some hidden transcripts and ambiguous ideas in the story of the land. It becomes important to pay attention to Schwarz who remarks: 'It does not take two to make a fight. An idea in the mind of one is enough' (1960:4). The word settlers is deep-rooted in the conscious and subconscious minds of most people and must be redefined. This is because Europeans in South Africa or Zimbabwe are no longer settlers, but bona fide Africans. Furthermore, the word ancestor(s) should suggest a collective term that describes the matriarchs and patriarchs of all race groups in South Africa, presuming that present landowners cannot be held responsible for the injustices of the past in a new South Africa where all races now have common ideals of political unity and a felt sense of nationality.

Vorster's anthropology focuses on the individual who emerges from the territorial groupings beginning with the community, the tribe and nation, state and country. In the context of the new South Africa's new liberal democracy, the ethical concerns for the protection of the human rights of women, children and homosexuals becomes Vorster's immediate focus. Vorster's cognisance of the individual is in recognition of the fact that society is nothing but the accumulation of individuals. This does not mean that Vorster defies the individual as the measure of all things. Rather, his perception of the individual is close to that of Bentham who defines the community as a 'fictitious body composed of the individual persons who are considered constituting, as it were, its members' (Bentham 1789:4). The human rights of citizens, the well-being of children and women constitutes a major component part of Vorster's anthropology.

\section{The protection of children and the Human Rights of women}

Virginia Woolf is credited to have said that:

Even when the path is normally open - when there is nothing to prevent a woman from being a doctor, a lawyer, a civil servant there are many phantoms and obstacles, I believe looming in her way. (Quoted in Adair 2002:276)

Not very often would one find African male academics contesting for the fair treatment of women in the African society. Vorster has identified with African feminine scholars such as Mercy A.E. Oduyoye, Isabel A. Phiri, Musa W. Dube, Sarojini Nadar amongst others who championed the cause of African women, religion and health issues and predicaments.

18.Also see Institutes 1. 16. 3; Mario Miegge, 1 Talenti Messi a Profitto (Urbino Argalia 1969), 7, 11-13; André Biéler, La pensée économique et sociale de Calvin (Geneva: Librairie de I'Université 1961:321). 
Anna Mary Mukamwezi Kayonga (1999:140-141) laments that 'in most African cultures women are mere slaves who are there to look after children and be treated like dirt ... on the whole the majority of African women are oppressed' The Human Rights Council of the United Nations' (UNHRC). annual report mentions the many cases of violence against women, trafficking, exploitation and violation of their basic rights. In all, women are more prone to perennial poverty and HIV infection as a result of their predicament. ${ }^{19}$ Vorster's (2007:188) ethical concern is that Christianity and Liberal Democracy in South Africa are still challenged with the general perception of female inferiority. For this reason, 'Christianity must become an agent of liberation of women' (Vorster 2007:188). Vorster's ethical position on the dignity of women takes its root from the Western tradition of leadership that has its source both in classical and biblical fountains. Vorster would endorse the philosophy of Socrates who proposed that where women know more than men about spinning wool, then they rightly become the leaders. For Socrates, authority is grounded in having the knowledge appropriate to the situation in which those concerned find themselves. Therefore, authority must flow from the one who knows, and this applies impartially to women as well as men. 'You will admit' he says in the Republic, 'that the same education which makes a man a good guardian will make a woman a good guardian; for their original nature is the same?' (Plato 1928b:407). Furthermore, Socrates says:

... there is no special faculty of administration in a State which a woman has because she is a woman, or which a man has by virtue of his sex, but the gifts of nature are alike diffused in both; all the pursuits of men are the pursuits of women also (Plato 1928b:406 $)^{20}$

Vorster (2007:192-200) would amplify Socrates' position using the biblical theological motifs of:

[T] he equality of men and women in creation and fall; God's covenantal relation with His people; the Kingdom and the formation of the church; and the redemption in Christ and the gift of the Holy Spirit, [to substantiate the equality of men and women.]

By achieving this objective, Vorster breaks with the philosophy of Western thinkers, of which some famous examples include Aristotle, who believed that women were deformed men; Immanuel Kant, who found it thoroughly improper for a woman to display any interest in intellectual or technological pursuits, even if she might be good at it; Rousseau, who saw a woman as a man's helpmate and little else; and Nietzsche, who admired women for being more 'natural than men but vilified them for being inconsistent'. Nietzsche (1954) further shares his insight on females when he said:

Everything in woman is a riddle, and everything in woman has one solution - that is pregnancy. Man is for woman a means: the purpose is always the child. But what is woman for man? A real man wants two things: danger and play. Therefore he wants woman as the most dangerous plaything. Man shall be educated

19.See for instance the United Nations, Report of the Special Rapporteur on Trafficking of Persons, especially Women and Children', Geneva, United Nations, 2004. (Document E/CN,4/2005/71\&72).

20.Greek philosophers would still maintain that 'in all, a woman is inferior to a man' But Socrates would ask, 'are we to impose all our enactments on men and none of them on women?' (Plato 1928b:406). for war, and woman for the recreation of the warrior: all else is folly. (pp. 178-179)

Apart from scriptural conviction as a theologian and ethicist, Vorster's anthropology incorporates John Stuart Mill, who was the first influential philosopher, to suggest that although men and women have different capacities, they should nevertheless be given equal opportunities and equal respect for their abilities (Rosenstand 2000:443). For Vorster (2007:193-194) 'The totality of biblical anthropology should be taken into account' when dealing with the position of women in society and the equality of all humankind. In sum, Vorster upholds the philosophy that Christian biblical hermeneutic, especially as expressed in the classic reformed confessions, must support the liberation of women in the church and also in society. Christians are to manifest the attitude of Christ by taking the human dignity of women to heart and by championing women's rights in the community (Vorster 2007:189).

Vorster would not uphold Christian theologies that tend toward establishing a doctrine and culture of the subordination of women, or refuse to pay attention to the position of women within the framework of salvation history. 'Biblical anthropology', he says, 'runs against any form of patriarchism and discrimination against women in church and society' (Vorster 2007). The fact remains that:

$[N]$ o Liberal Democracy can claim success in maintaining law and order and the values of human dignity, equality and freedom if it does not solve the problem of the current inferior state of women in its own midst. (p. 207)

Furthermore, Vorster's ethical concern is that any steps to healing the South African past experience must invoke the responsibilities of parents and the state towards protecting the most vulnerable, the children.

\section{Protecting the most vulnerable: A focus on children}

Vorster's anthropology further places the most vulnerable in cosmological perspective and maintains that child abuse and the neglect of children have become a universal concern for all humanity. For the sake of children worldwide, there have been several declarations made on behalf of the children's rights beginning with the 1954 Geneva Declaration of the Rights of the Child. This declaration led to the Universal Declaration of the Rights of the Child in 1959. Subsequently in 1966, the International Covenant on Civil and Political Rights of the Child was launched. In Addis Ababa, Ethiopia, the Organisation of African Unity (now African Union) recognised the need to take all relevant measures to foster, promote and protect the rights and the social, economic and cultural welfare of the African child. In recent times, the United Nations International Children Education Fund (UNICEF) through the then General Secretary Kofi Annan (2004), assessed the general estate of the world's children, and reported that:

$[N]$ o future can be built without the restoration of the human dignity of many children in the world - the most vulnerable group within societies. The restoration of the human dignity of children is not only a prerequisite for a peaceful and prosperous 
future for many communities today, it is a God-given moral obligation. (p. vii)

It has been noted that Vorster's anthropology is rooted in human creation in the image of God so that, 'the special status of children in Scripture is further determined by their inclusion within the Covenant' (Vorster 2007:217). Children's participation in the Covenant relationship and in the redemptive work of Jesus Christ affirms their being included as complete members of the body of Christ. Vorster's anthropology underscores the fact that the human dignity of children is founded in their creation in the image of God (Vorster 2007:220). This point becomes very crucial against the report that by 2008, 3.95 million children in South Africa had lost one or both of their parents resulting in a high risk of missing out on schooling, lower food security, anxiety and depression, and exposure to HIV (South African Theological Seminary 2011). This report confirms that when society chooses to abandon biblical principles for building marriages, homes and the families, societal disaster becomes inevitable. The place of children in the society as the most vulnerable bearers of God's image is crucial and vital for Vorster's humanism. Vorster stands by Scripture that children are included in the redemptive sacrifice of Christ on the cross with a special right to protection. There are many groups in society, like the family and the church, which do influence the social life of children. For this reason, the majesty that Jesus Christ accorded children must be mirrored in the church and society. Vorster's anthropology recognises children as redeemed people in Christ who followed Christ and 'were presented to be touched and blessed by him' (Vorster 2007:219). Jesus' blessing of the children is an act of love, respect and recognition.

Vorster (2007) recommends three kinds of actions Christians should take to mitigate the plight of children: exemplariness, by which he infers that:

[T] he major task of Christians ... is to set an example to society at large by honouring and advocating the human dignity of children and by treating their children in a loving and caring way. (p. 222)

Protest, by which Vorster challenges Christians and churches to be vocal protestors in favour of children in distress, in the present reign of child labour, use of children as soldiers, child-trafficking, corporal punishment, abuse, neglect and use of children in pornography (2007:223). Worth noting is Vorster's (2007) appeal to history:

[J]ust as churches played a major part in the struggle against apartheid by raising awareness of the ill effects if the system, they can do the same on behalf of the children of South Africa. (p. 223)

Healing, by which Vorster reminds the church that the Christian community is a sphere of healing with facilities for accommodating the abused and neglected street children (ibid.). Further, Vorster's historical appeal reminds that, 'in the past, churches established schools, hospitals and orphanages', greater, but not surpassing this deed, is what Vorster sees as a felt need of these children, which is love, warmth and hope of a close caring community of people becoming 'brothers' and 'sisters' in concrete terms (Vorster 2007:225).

The pedagogue in Vorster is aware of the composition of the human personality for developing the self-discipline necessary for their spiritual and intellectual safety and for self-reliance in coping with needs. Further, Vorster's anthropological theology is aware that the child, as any other human being, is a spiritual being and of ontological and religious significance. If the child's basic corporeal, rational and spiritual dimensions of life are not developed, it grows up to become a liability to the family and the society. A society that does not uphold the control and superiority of the soul and/or mind over the body produces children unfit to wellplay redemptive roles that are social, political, economic, religious et cetera. And when these redemptive roles are not received and imbibed from childhood onwards, the expected national manifestations are unethical behaviourisms such as xenophobia and human rights abuse.

\section{Racism, xenophobia and human rights}

As a matter of fact, Vorster, the anthropologist, is aware that nothing can be produced nor can there be any change, progress, development, culture and civilisation without humankind. As a result, his anthropological philosophy focuses on human life, human rights and the preservation of human life. Vorster (2004) says:

The right to life as a fundamental right in the human right debate should be supported from the Christian ethical perspective. The right to life and the duty to preserve life is a clear biblical principle. The increasing legislation of abortion on request, the application of capital punishment and the legislation of euthanasia as the ending of life are in contradiction to the right to life. (p. 138)

Vorster (2007:141) engages ethical issues of race consciousness and its articulation in three main factors: ideology, greed and fear. It becomes obvious that Vorster's anthropology based on the imago Dei - human creation in the image of God seeks to remove the concept of race from fundamental social, political and economic determination in South Africa's liberal democracy. The race discourse is very important to Vorster because of its historical rigid root with socio-economic and political consequences for South Africa.

\section{Racism: What is it?}

Racism is the view based on the idea that humankind is divided into naturally distinct races which can be ranked in order of superiority, and which ascribe to another race inferior or dangerous qualities. It is in fact the practice of discriminating on grounds of race to the disadvantage of the members of the other race (Mautner 2005:516). No matter how philosophically or ethically defined, racism is an ideology or worldview that makes race one of the key defining characteristics of a people or person. Take for example the striking description offered by Holcombe (1861): 
The Negro is not a white man with a black skin, but a different species, ... the hopeless physical and mental inferior (of the white, and) organically constituted to be an agricultural laborer in tropical climates - a strong animal machine. (p. 403)

Vorster defines racism as 'an attitude of prejudice, bias and intolerance between various racial groups'; and mentions three factors that are responsible for racism: 'ideology, greed and collective fear' (Vorster 2004:140). But over and above this, Vorster does not view religion as the ground for racism, but argues that religions are often misused to legitimise racist ideologies. Vorster (2009b) testifies that a church community in a Christian tradition in South Africa - of which he was a member - is accused of scripturalism:

Afrikaners held the political power in South Africa for many decades. They instituted the policy of $[a]$ partheid in an effort to maintain an own cultural identity over and against the British on the one hand, and the growing African nationalism on the other. (p. 74)

Vorster is aware of the existence of older views of philosophers of racism beginning with the theories of Aristotle and Plato, which elitists have used to justify racism. In fact, Vorster would break with John Locke's natural rights ethics or theory that became the basis of the colonial rights discourse. Perhaps, sensitivity to the seeming factuality of scientific claims must have compelled Vorster to make minimal or no reference to the works of great philosopher-scientists like Carolus Linnaeus (1707-1778); David Hume ([1748] 1996) who alleged that all Negros were of low intelligence, and says:

I am apt to suspect the Negroes to be naturally inferior to the Whites. There scarcely ever was a civilised nation of that complexion, nor even any individual, eminent either in action or speculation. No ingenious manufactures amongst them, no arts, no sciences. On the other hand, the most rude and barbarous of the Whites, such as the ancient Germans, the present Tartars, have still something eminent about them, in their valour, form of government, or some other particular. Such a uniform and constant difference could not happen, in so many countries and ages, if nature had not made an original distinction between these breeds of men. Not to mention our colonies, there are Negro slaves dispersed all over Europe, of whom none ever discovered the symptoms of ingenuity; though low people, without education, will start up amongst us, and distinguish themselves in every profession. In Jamaica, indeed, they talk of one Negro as a man of parts and learning; but it is likely he is admired for slender accomplishments, like a parrot who speaks a few words plainly. (p. 228)

Further is the Lamarkian theory of the inheritance of acquired traits, furthered in a speculation that the:

$[I]$ ncreased presence of strong liquors in southern lands contributes to their moral inferiority: You may obtain anything of the Negroes by offering them strong drink, and may easily prevail with them to sell, not only their children, but their wives and mistresses, for a cask of brandy. (Hume [1748]1996:235)

Jean-Jacques Rousseau also speculated that the great apes were really humans (the people of Africa) whose evolution had been stunted by adverse environmental conditions. Thomas Jefferson (1743-1826) equally accepted the inequality of hereditary endowment in the different human races
(Jefferson 1955). Furthermore, there is the Marxist linking of racism to capitalism and class exploitation.

From a religious perspective, there have been debates to reconcile the Bible with the existence of racially distinct people:

Arguments took place over creation itself, as theories of polygenesis questioned whether God had made only one species of humanity ('monogenesis'). Europeans wondered if the natives of the New World were indeed human beings with redeemable souls. (Omi \& Winant 1986:20)

Furthermore, God has been charged as the mastermind of racism. It is said that:

$[T]$ here is an intentional imbalance of suffering, with more being apportioned to the outer group than to the in group; God has willed this imbalance; his favour or disfavor being correlated with racial or ethnic identity. (Erickson 1983:560) ${ }^{21}$

Josiah Priest (1852), using his thesis to justify the inequality of slaves and slaveholders, went so far as to deny the humanity of Black people as creatures without souls (Priest 1852:560). On what is this categorisation based: attitude, religion or general pattern of human development and group mannerism? In the Bible Gentiles refers to non-Israelites or non-Jews. Circumcision, a covenant sign on Abraham and his descendants symbolised consecration to God. The Gentiles, as uncircumcised, were indeed the people of rebellion and disobedience, stubbornness and unbelief, the wild olive tree in contrast to the good olive tree. The Jews regarded Gentiles as dogs because of their way of life (Mt 15:26; Mk 7:27). Are there no clear socio-political, ethico-scientific differences between Africans and Europeans or Asians and Americans? Is it ethical to play down some implicit and explicit factors that make races different one from the other? Often racism has been subjected to universal criticism more than its cognate endemic problem of tribalism and nepotism in Africa. Christian ethics must seek to address the treatment of these two sides of the same social problem. Vorster is aware of the philosophical works of the above-mentioned thinkers and their counterparts from the religious side.

From purely biblical perspectives, Vorster submits that 'the method of distinguishing people according to race is alien to the Bible, because it violates the principles of human dignity, the commandments of love, social justice and unity' (Vorster 2004:152). Vorster tenaciously upholds the unity of humankind expressed in the imago Dei. This unity as found in the Christian Bible abrogates any government's action or policy with potentiality to divide and oppress. Consistent with Vorster's anthropology, 'any notion of the superiority and inferiority of people due to gender, class, race, culture, ethnicity or religion distorts the Biblical view of man [sic] (ibid.). In fact, 'the ideology of the natural inequality of people, based on the reality of pluralism, cannot be justified from a Biblical perspective' (ibid.). These ethico-biblical injunctions will continue to be Vorster's philosophical ideal for a decent co-existence of all people in South Africa's Liberal Democracy.

21.William Jones (1973) in his book Is God a White Racist argued from the them 'divine racism' that divides humanity into two categories of 'we' (in) and 'they' (out). Jones's theory is that God does not value all persons equally. 


\section{Critical evaluation}

What has been offered in the foregoing pages is an exposition of J.M. Vorster's ecclesio-political philosophy. The remaining task here is to assess and evaluate the merits of Vorster's views. How to go about evaluating Vorster and the methods and criteria for doing this exercise remains a future academic task of Vorster's students. Evaluation may be by means of synthetic or analytic methods. The synthetic method generally considers salient and essential features of a work; it is liberal and often tries to bring out categories and concepts that could have remained hidden and unmentioned in the course of interpretation. Furthermore, the synthetic method of evaluation endeavours to open horizons for the discussions of new issues. This method will not be followed in evaluating Vorster because it is necessarily restrictive. The analytic method is detailed and elaborate, however, it tends to repeat or review all over again almost everything that went before it.

One of the contributions of Vorster is that in his anthropological ideas, he probed and thought deeply about the nature of humanity. In his theological ideas, the Scripture, the church and the general ethical responsibility of postapartheid South African society was his main preoccupation. Vorster has shown through his ecclesio-political philosophy that humankind is not a mere collocation of material atoms. Homo sapiens, whose habitat is South Africa, Europe, Australia, America or Asia, is the same in nature and exhibits the same general characteristics and evinces the same reaction under a given political situation..$^{22}$ The doctrine of the universality of human nature is obviously not new. Authentic humanism for Vorster is both horizontal and vertical; faith in God and the protection of imago Dei take the centre stage of his socio-political and ethical discourse. Vorster, like Aristotle and Calvin, emphasises the sociality of human nature and rejects the theory of society brought about by fear, dominance, apartheid or military conquest. Besides, in dealing with liberal political issues in post-apartheid South Africa, Vorster rejects the use of violence that is permitted by Locke (1632-1704) as a means of redress in society. Vorster's present-day society is not like the abstract and totalitarian society of Hegel or the apartheid government of the 1940s. For Vorster, the unique individual and person still remain the basis of society. For this reason, he offers ethical solutions to the problems of nation-building, land restitution, compassion for the poor, fair-minded affirmative action, racism, xenophobia and human rights.

It is clear then that human freedom and abundant life for all in South Africa is central to the ecclesio-political philosophy of Vorster. Human freedom in South Africa implies 'a market driven economy on the one hand, and the state that

22 . One needs to thoroughly read Vorster's treatment of Christian theory of human rights (Vorster 2004:85-103) in his well-known book Ethical Perspectives on
Human Rights, the first edition, which was published in 2004. The political pole in Human Rights, the first edition, which was published in 2004. The political pole in South Africa is now elevated in which the majority of people are on top of things The other end of the pole is painfully pitching at the White minority whose voices are hushed. Now, Vorster finds himself writing and fighting against similar sociopolitical ills he fought against during the apartheid era. Present political turnaround in Southern Africa graphically authenticates Vorster's awareness of the universality of human thought and behaviour. is directly involved with poverty alleviation on the other hand ...' (Vorster 2007:74). ${ }^{23}$ The neo-liberalist philosophy that engineered the market-driven economies of developed countries cannot help South Africa with large-scale poverty. Vorster would say in regard to South Africa, that '... the economy has grown; but it has not really contributed to poverty alleviation during the last ten years' (ibid.). From this perspective, Vorster's philosophy is that socio-economic and political development should promote equality, justice, love, reconciliation, forgiveness, vocation and compensation and not violence, strikes, unemployment or affirmative actions applied as punishment or job creation for one group of the community and unemployment for another part of the community; ${ }^{24}$ and that problems arising there from should be resolved constitutionally (Vorster 2007:108-110). This goes to show that Vorster as a Christian ethicist firmly holds the biblical anthropology as the basis of his ecclesio-political philosophy. There is nothing that concerns and worries the mind of Vorster more than the presence of socio-economic injustice in governance and the distribution of wealth in post-apartheid South Africa. The observed aberration is that Vorster is talking and writing against the ethical evils of neo-liberalism and classical capitalism whilst the presentday South African Church remains ambivalent and silent on these issues.

With due credit to Vorster, he rightly perceived the numerous ethical problems of post-apartheid South Africa in its ontological dimension when he traced the Fall and original sin, which has distorted human's attitude. Where Vorster needs to be quizzed on, is his treatment of South Africa's ethico-social and political problems like that of a Christian nation. Would Vorster submit that the unregenerate does have the capacity to follow the pathways of 'love, stewardship, self-denial and obedience to God and the characteristics of Christian attitude?'25 Would Vorster agree that social justice, equal opportunity, affirmative action, human rights, racism, xenophobia, minority rights, as a goal and good ideal is not the prerogative of Christian ethics, but that these are actually derived from democracy? However, Vorster's perception of ethical perspectives and Christian attitude in the South African liberal democracy can serve as an evangelistic approach to deal with South African citizens of different religions and political persuasions.

\section{Toward a conclusion}

The reader may be right to ask what is the synopsis and summary of this exercise. No human thought and system is perfect, otherwise scholarship would have ended long ago.

23. Neo-liberalism is the philosophy in which state initiatives in the economy should be limited as far as possible to let the markets control the economy unhindered and the limitation of interference from the state in the economic sphere. The neoliberalist philosophy determined the economies of the developing countries in a more or less degree since the eras of Margaret Thatcher and Ronald Reagan. This philosophy resulted in great economic growth in developed countries but never helped to bring immediate relief in most developing countries with large-scale poverty.

24.See especially the discussion of 'Fair-Minded Affirmative Action' in Chapter 5 and 'Stewards in the Workplace' in Chapter 6 in Vorster's (2007) book Christian Attitude in the South Africa Liberal Democracy.

25.Vorster (2007:20) recommends the teachings of Christ of the attitude of Christ as a basis for Christian ethical principles ... in a modern world. 
Philosophy is said to thrive on detecting imperfections and defects in theories, views and opinions so that culture and civilisation are promoted and ensured. Ideas rule the world, but Vorster as a scholar, like other scholars, would control human affairs and society. The study of the ecclesio-political philosophy of Vorster shows its relevance to contemporary scholarship. It in fact directs its appeal to the conscience of scholars everywhere about the need for the recognition of the universal dimension of thought, knowledge, culture and ethics. In this regard, Vorster seeks a change of attitude on the part of fellow South Africans toward a deontological ethical principle that defines the right political attitude amongst citizens in post-apartheid South Africa. The point is that 'social recesses cannot succeed if they are not carried by honest and committed people; Churches should play an important part in the development of a new attitude' (Vorster 2007:262). And for sure, the church has the capacity to influence and exert the power of righteousness in South Africa's new liberal democracy.

\section{References}

Adair, J., 2002, Inspiring leadership, Thorogood Publishing, London.

Annan, K.A., 2004, 'Foreword', in UNICEF, The State of the World's Children 2005, Childhood under Threat, p. vii, UNICEF, New York.

Appadorai, A., 1961, The Substance of Politics, Oxford University Press, Madras.

Bentham, J., 1789, An introduction to the principles of morals and legislation, Clarendon Press, Oxford.

Boss, J.A., 1999, Analyzing Moral Issues, Mayfield Publishing, Toronto.

Calvin, J., 1948, Commentary on Genesis, vol. 1, Eerdmans, Grand Rapids.

Chaplin, J., 1995, 'Kuyper, Abraham' in D.J. Atkinson \& D.H. Field, (eds.), New Dictionary of Christian Ethics and Pastoral Theology, pp. 533-534, InterVarsity Press, Downers Grove, IL.

Copleston, F., 1950, A history of philosophy: Medieval philosophy, Continuum, London. Erickson, M.J., 1983, Christian Theology, 2nd edn., Baker Books, Grand Rapids, MI.

Gevisser, M., 2007, The Dream Deferred: Thabo Mbeki, Jonathan Ball Publishers, Cape Town.

Holcombe, W.H., 1861, 'Characteristics and Capabilities of the Negro Race', Southern Literary Messenger 33 (December), 401-410.

Hume, D., [1748] 1996, The Philosophical Works of David Hume, vol. 3, Of Nationa Character, Thoemmes Continuum, London.

Jefferson, T., 1955, Notes on the State of Virginia, W. Peden, (ed.), University of North Carolina Press, Chapel Hill.

Jones, W.R., 1973, Is God a White Racist?, Doubleday, Garden City, NY.

Kayonga, A.M.M., 1999, 'African Women and Morality' in J.N.K. Mugambi \& A. Nasimiyu-Wasike (eds.), Moral and Ethical Issues in African Christianity: A challenge for African Christianity, pp. 137-151, Acton Publishers, Nairobi.
Mandela, N., 1994, Long walk to freedom: The autobiography of Nelson Mandela, Abacus, London.

Marshall, P., 1991a, Calling, Work, and Rest, Potchefstroom University for Christian Higher Education, Potchefstroom. (Institute for Reformational Studies, study pamphlet, no. 281).

Marshall, P., 1991b, A Calvinist Political Theory, Potchefstroom University for Christian Higher Education, Potchefstroom. (Institute for Reformational Studies, study pamphlet, no. 283).

Mautner, T., 2005, Dictionary of Philosophy, Penguin Reference, London.

Newell, P., 1991, The UN Convention and Children's Rights in the UK, Nationa Children's Bureau, London.

Nietzsche, F., 1954, 'On Little Old and Young Women', transl. W. Kaufman, in Thus Spoke Zarathustra, pp.178-179, Penguin Books, New York, NY.

Omi, M. \& Winant, H., 1986, Racial Formation in the United States: From the 1960 s to the 1990, Routledge, London.

Partee, C.J., 1995, 'Calvin, John', in D.J. Atkinson \& D.H. Field, (eds.), New Dictionary of Christian Ethics and Pastoral Theology, pp. 209-211, InterVarsity Press, Downers Grove, IL.

Plato, 1928a, 'Phaedo', in I. Erdman (ed.), The works of Plato, pp. 109-189, The Modern Library, New York, NY.

Plato, 1928b, 'Republic' in I. Erdman (ed.), The works of Plato, pp. 397-478, The Modern Library, New York, NY.

Priest, J., 1852, Bible Defense of Slavery: Origin, Fortunes and History of the Negro Race, 5th edn., W.S Brown, Glasgow.

Reid, W.S., 1957, 'The Christian in the World, A Facet of Calvin's thought', The Gordon Review 3, 52-61.

Rosenstand, N., 2000, The Moral of the Story: An introduction to Ethics, Mayfield Publishing, London.

South African Theological Seminary, 2011, 'General Newsletter, 25 May 2011', viewed on 30 May 2011, from http://www.satsonline.org/content/general-newsletter

Spykman, G.J., 1984, Calvinism in America - Review and Reflections, Potchefstroom University for Christian Higher Education, Potchefstroom. (Institute for Reformational Studies, study pamphlet, no. 193).

Van der Walt, B.J., \& Naudè, C.F.B., 1996, Christianity and Democracy in South Africa: $A$ vision for the future, Potchefstroom University for Christian Higher Education Potchefstroom. (Institute for Reformational Studies, study pamphlet, no. 345).

Vorster, J.M., 1992, The Failures of Christianity in Africa, Potchefstroom University for Christian Higher Education, Potchefstroom. (Institute for Reformational Studies, study pamphlet, no. 292)

Vorster, J.M., 1999, An introduction to Reformed Church polity, Potchefstroom Theological Publications, Potchefstroom.

Vorster, J.M., 2004, Ethical perspectives on human rights, Potchefstroom Theological Publications, Potchefstroom.

Vorster, J.M., 2006, 'The Ethics of Land Restitution' Journal of Religious Ethics 34(4), 685-707. http://dx.doi.org/10.1111/j.1467-9795.2006.00290.x

Vorster, J.M., 2007, Christian Attitude in the South African Liberal Democracy, Potchefstroom Theological Publication, Potchefstroom.

Vorster, J.M., 2008, The Challenge of Contemporary Religious Fundamentalism, Church History Society of South Africa, Pretoria.

Vorster, J.M., 2009a, 'An ethics of forgiveness', Verbum et Ecclesia 30(1), 365-383.

Vorster, J.M., 2009b, 'Forgiveness and impunity in a situation of transition: A sociopolitical perspective', Missionalia 37(1), 66-84.

Wright, C.J.H., 1990, God's People in God's Land: Family, Land and Property in the Old Testament, William B. Eerdmanns, Grand Rapids, MI. 